\title{
PERSEPSI KEPEMIMPINAN DAN MOTIVASI TERHADAP KINERJA KARYAWAN PADA PT ASURANSI BINTANG
}

\author{
Richard Tobing \\ Yohana F. Cahya Palupi Meilani
}

\begin{abstract}
Abstrak
Perusahaan-perusahaan yang mampu bertahan dan menang dalam persaingan adalah perusahaan yang mampu mengelola sumber daya yang dimiliki.Salah satu sumber daya terpenting adalah sumber daya manusia. Faktor ini akan menjadi semakin penting dalam era globalisasi, mengingat bahwa keberhasilan perusahaan tidak lagi hanya ditentukan oleh kemampuan menghasilkan suatu produk atau jasa yang dibutuhkan konsumen, namun sangat dipengaruhi oleh bagaimana perusahaan mampu menyediakan, mengelola, memelihara, serta mengembangkan sumber daya manusia agar dapat mendukung seluruh aktifitas perusahaan. Tujuan penelitian ini adalah untuk mengetahui persepsi kepemimpinan dan motivasi terhadap kinerja karyawan pada PT Asuransi Bintang.Variabel-variabel yang dipakai dalam penelitian ini adalah kepemimpinan, motivasi dan kinerja karyawan.Pengumpulan data dilakukan dengan judgemental sampling (purposive sample), menyebarkan kuesioner kepada karyawan dan karyawati PT Asuransi Bintang.Data diolah dengan menggunakan analisis regresi.Pengukuran dilakukan dengan menyebarkan kuesioner kepada 50 responden, yang kemudian diuji reliabilitas, dan validitasnya. Setelah itu baru dilakukan penyebaran kepada 103 responden untuk uji aktual test serta dilakukan analisis yaitu dengan multiple regression dengan menggunakan SPSS versi 15. Dari hasil pengolahan data, disimpulkan bahwa kepemimpinan dan motivasi mempunyai persepsi yang signifikan terhadap kinerja karyawan.Satu kesimpulan yang dapat diambil adalah kepemimpinan dan motivasi bagi karyawan yang mampu menambah gairah atau semangat kerja pada karyawan adalah dengan membangun komunikasi antara atasan dan bawahan secara intim (communication climate).Komunikasi intim antara atasan dan bawahan menciptakan suasana kerja yang nyaman dan turut mendukung pembentukan budaya kerja yang baik.
\end{abstract}

Kata kunci: Kepemimpinan, Kinerja Karyawan, Motivasi

Perusahaan harus didukung oleh karyawan yang berkualitas dan potensial agar dapat berkompetisi dalam persaingan. Dalam menjaga eksistensinya di dalam persaingan dunia saat ini diharuskan memanfaatkan segala potensi yang dimiliki. Salah satu caranya adalah dengan memaksimalkan kinerja karyawan. Karyawan merupakan sumber daya penting bagi perusahaan, karena memiliki bakat, tenaga, dan kreativitas yang sangat dibutuhkan oleh perusahaan untuk mencapai tujuannya (Muljani 2002, 108). Salah satu faktor yang dapat meningkatkan motivasi adalah kepemimpinan. Kepemimpinan yang efektif merupakan persyaratan vital bagi kelangsungan hidup dan keberhasilan organisasi (Wexley \& Yukl 2008, 189). Selain gaya pemimpin dalam memimpin perusahaan, hal ini juga mencakup gaji, bonus, 
dan tunjangan yang diberikan oleh pemimpin. Berdasarkan data personalia dan hasil wawancara dengan Kepala Divisi Sumber Daya Manusia PT Asuransi Bintang dirumuskan atau dilihat adanya suatu masalah. Dari 178 orang karyawan hanya 69,1\% kinerja karyawan yang dapat mencapai target, sementara ekspektasi perusahaan adalah 90\%. Dan berdasarkan hasil wawancara secara langsung terhadap beberapa masalah antara lain, karyawan merasakan kurangnya komunikasi langsung dengan atasan untuk berbagi informasi, pengalaman dan masukan mengenai selukbeluk dunia asuransi dan ini berdampak pada kepercayaan karyawan, secara khusus agen asuransi dalam memperkenalkan dan menjual produk asuransi pada konsumen. Berikutnya, karyawan atau agen merasa perlu mendapat penilaian hasil kerjanya secara berkala agar mereka mengetahui sejauh mana kinerja mereka. Dari sudut pandang Expectancy Theory, para pekerja tidak termotivasi untuk bekerja keras karena merasa tidak adanya hubungan antara prestasi kerja dengan penghasilan. Dan yang terakhir adalah masalah reward atau penghargaan yang didapatkan oleh karyawan jika hasil kerja mereka mencapai target. Kesimpulannya adalah karyawan menuntut insentif yang lebih baik serta sistem reward dan punishment yang jelas. Banyak faktor yang bisa mempengaruhi kinerja karyawan dan menjawab permasalahan tersebut, namun karena beberapa alasan maka penelitian ini memilih faktor kepemimpinan dan motivasi. Berdasarkan latar belakang masalah di atas, maka permasalahan penelitian yang muncul dapat dijabarkan sebagai berikut:

(1). Apakah kepemimpinan dan motivasi secara bersama-sama berpengaruh positif terhadap kinerja karyawan PT Asuransi Bintang?

(2). Apakah kepemimpinan berpengaruh positif terhadap kinerja karyawan PT Asuransi Bintang?

(3). Apakah motivasi berpengaruh positif terhadap kinerja karyawan PT Asuransi Bintang?

Manajemen Sumber Daya Manusia menurut Armstrong (2013, 11), manajemen sumber daya manusia adalah manajemen suatu perusahaan terhadap aset yang paling utama dari suatu perusahaan, yaitu sumber daya manusia, yang dilakukan secara strategis dan berkesinambungan. Cascio $(2006,39)$ menyatakan tanpa sumber daya manusia, organisasi tidak dapat berfungsi, sebaliknya manusia 
perlu organisasi agar dapat memuaskan kebutuhan dan keinginannya sehingga mereka dapat memelihara dan menjaga standar hidup yang sudah dimiliki.

Perilaku organisasi merupakan sebuah ilmu yang berdampingan dengan ilmu sumber daya manusia, karena menurut Kinicki dan Kreitner (2011) perilaku organisasi bisa digunakan untuk membantu memahami cara untuk mengerti dan mengatur individu yang bekerja di dalam sebuah organisasi, tetapi perilaku organisasi bukan merupakan ilmu yang berdiri sendiri melainkan dibentuk dari beberapa bidang ilmu lain.Sementara itu menurut Gibson et al. (2011) dalam bukunya mengenai perilaku organisasi menyatakan bahwa perilaku organisasi merupakan gabungan dari beberapa ilmu yang bisa digunakan dalam membantu memahami seorang individu yang ada di dalam organisasi sekaligus membantu menganalisa faktor-faktor eksternal yang bisa berpengaruh pada organisasi tersebut.

Kouzes dan Posner (2007, 20), kepemimpinan adalah suatu usaha untuk membuat orang lain berkontribusi demi mencapai sesuatu yang hebat. Sedangkan kepemimpinan adalah suatu usaha untuk mempengaruhi orang lain untuk melakukan apa yang kita inginkan atau kita ingin wujudkan, ada 2 tipe pemimpin:

(1). Transaksional: tipe pemimpin yang sangat memperhatikan sasaran dalam perusahaan dan bagaimana sasaran itu bisa terwujud dengan sistem reward and punishment.

(2). Transformasional: tipe pemimpin yang sangat menekankan pada gambaran besar terhadap pekerjaan dan mampu memotivasi karyawan untuk bekerja dengan lebih baik(Burns, 2013:89-90).Fungsi kepemimpinan menurut Hill dan Carol (2007) memiliki dua dimensi:

1.1. Dimensi yang berkenaan dengan tingkat kemampuan mengarahkan (direction) dalam tindakan atau aktivitas pemimpin, yang terlihat pada tanggapan orang-orang yang dipimpinnya.

1.2. Dimensi yang berkenaan dengan tingkat dukungan (support) atau keterlibatan orang-orang yang dipimpin dalam melaksanakan tugas-tugas pokok kelompok atau organisasi, yang dijabarkan dan dimanifestasikan melalui keputusan-keputusan dan kebijaksanaan-kebijaksanaan pemimpin. Gaya kepemimpinan yang paling tepat adalah suatu gaya yang dapat memaksimalkan 
produktivitas, kepuasan kerja, pertumbuhan, dan mudah menyesuaikan dengan segala situasi (Davis 2004, 168).

Karyawan pada umumnya akan siap bekerja keras dan memiliki semangat bila menghadapi beberapa kondisi. Pertama, masing-masing karyawan merasa diperlukan oleh dan di dalam organisasi. Dengan demikian mereka menyadari bahwa hasil kerjanya bermakna atau memiliki arti yang penting bagi perusahaan dan akan dihargai. Kedua, setiap karyawan tersebut mengetahui dengan jelas apa yang diharapkan organisasi atau perusahaan dari mereka. Dengan demikian mereka dapat berupaya dengan sungguh-sungguh memenuhi harapan tersebut. Ketiga, para karyawan merasa diperlakukan secara adil baik antar pekerja maupun dalam pemberian imbalan atau penghargaan. Bila kontribusi karyawan dalam bekerja tidak dihargai dengan imbalan yang seimbang maka semangat kerja karyawan akan menurun. Keempat, para karyawan diberi kesempatan yang sama untuk berkembang dan meningkatkan kemampuan mereka bahkan untuk membangun karir hingga mereka mencapai karir yang paling tinggi dalam organisasi atau perusahaan.Kelima, karyawan diberi tantangan, baik dengan menciptakan pekerjaan yang menarik maupun dengan memberi kepercayaan untuk berkreasi dan berinovasi. Keenam, karyawan merasakan suasana kerja yang menyenangkan termasuk hubungan dengan atasan dan bawahan, serta hubungan dengan teman sekerja(Simanjuntak, 2005:95).

Kinerja pada dasarnya adalah apa yang dilakukan atau tidak dilakukan karyawan. Kinerja adalah suatu kontribusi positif terhadap perusahaan dan juga lingkungannya yang diberikan oleh karyawan dalam bekerja (Bourne, Franco, dan Wilkes,2003:98). Penilaian kinerja adalah suatu sistem yang digunakan untuk menilai atau mengetahui apakah seorang karyawan telah melaksanakan pekerjaannya sesuai dengan target yang telah ditentukan sebelumnya (Siagian 2003: $31)$.

Kepemimpinan yang efektif merupakan persyaratan vital bagi kelangsungan hidup dan keberhasilan organisasi.Salah satu faktor yang dapat meningkatkan motivasi adalah kepemimpinan (Wexley \& Yukl 2008, 189). H1: terdapat pengaruh positif kepemimpinan dan motivasi terhadap kinerja karyawan. Kepemimpinan adalah bagian penting dari manajemen, tetapi tidak sama dengan manajemen. 
Kepemimpinan merupakan kemampuan yang dimiliki seseorang untuk mempengaruhi orang lain agar dapat bekerja sama mencapai tujuan dan sasaran yang diinginkan. Lebih daripada itu, kepemimpinan adalah kesanggupan yang dimiliki oleh seseorang untuk mempengaruhi opini, sikap, dan tingkah laku orang lain menurut kepemimpinan (Mathis et al, 2014). H2: terdapat pengaruh positif kepemimpinan terhadap kinerja karyawan.

Motivasi sangat menentukan apa yang akan dilakukan oleh karyawan dan seberapa besar usaha mereka melakukan hal tersebut. Pada dasarnya motivasi dan kinerja merupakan dua aspek yang berbeda dari perilaku dalam organisasi, tetapi keduanya memiliki hubungan yang positif. Apabila motivasi karyawan terpenuhi maka akan timbul kepuasan kerja yang pada akhirnya akan meningkatkan kinerja karyawan. Jika karyawan diberikan penghargaan atau pengakuan untuk pekerjaan yang telah dilakukannya dengan baik maka hal tersebut merupakan motivasi bagi karyawan untuk meningkatkan kinerjanya (Griffin dan Moorhead, 2013). H3 : terdapat pengaruh positif motivasi karyawan terhadap kinerja karyawan.

\section{Gambar 1. Model Konseptual}

Berdasarkan dasar teoritis dapat dirumuskan model penelitianseperti berikut ini:

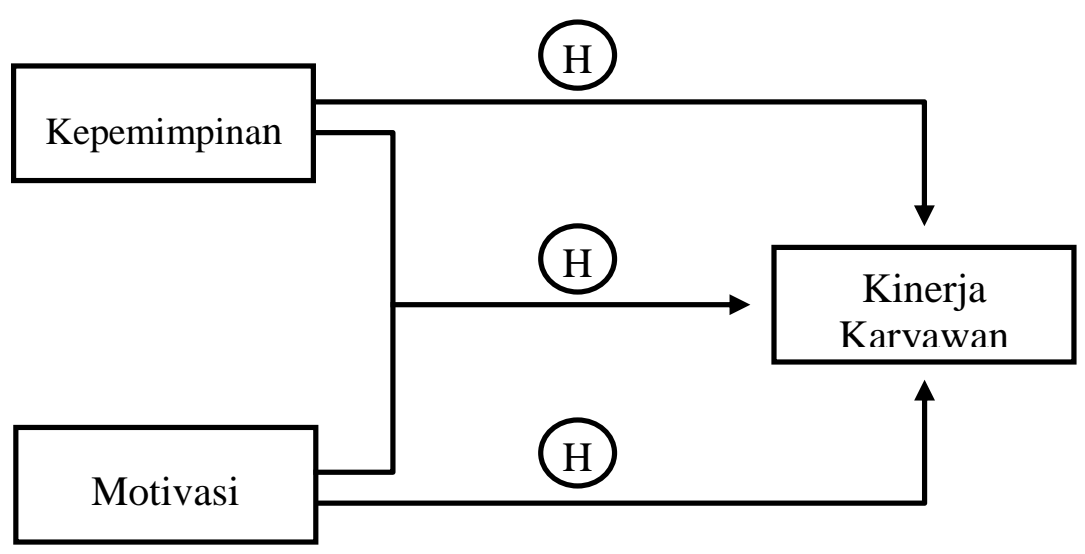

\section{Metodologi}

\section{Obyek Penelitian dan Subyek Penelitian.}

Obyek yang akan digunakan dalam penelitian ini adalah karyawan PT Asuransi Bintang yang bergerak di bidang jasa asuransi.Subyek penelitian adalah seluruh karyawan PT Asuransi Bintang yang berjumlah 178 orang. 


\section{Jenis Penelitian.}

Penelitian menggunakan jenis penelitian deskriptif.Alasan penelitian deskriptif.Penelitian deskriptif kuantitatif dapat dilakukan dalam dua cara yaitu dalam bentuk survei dan observasi. Survei dengan menggunakan kuesioner responden dalam mengumpulkan data.Dan observasi dengan melakukan observasi perilaku dan fenomena dalam mengumpulkan data (Malhotra 2009, 196).Dalam penelitian ini peneliti menggunakan teknik survei.

\section{Teknik Pengumpulan Data.}

Data yang digunakan dalam penelitian ini adalah data primer dan data sekunder. Data primer yaitu informasi yang diperoleh pertama kali sumber asli oleh peneliti, sedangkan data sekunder yaitu data yang sudah tersedia sehingga hanya mencari dan mengumpulkan. Data primer dalam penelitian ini didapat melalui kuesioner yang disebarkan pada responden. Sumber data primer dalam penelitian ini yaitu seluruh karyawan PT Asuransi Bintang. Data sekunder diperoleh dari studi literatur berupa teknik kepustakaan yang dilakukan dengan cara membaca bukubuku referensi yang berhubungan dengan penelitian dan jurnal-jurnal penelitian sebelumnya, serta informasi dan data personalia yang didapat dari hasil wawancara dengan kepala divisi Sumber Daya Manusia PT Asuransi Bintang.

\section{Desain Sampel.}

Desain yang digunakan dalam penelitian ini adalah non-probability sampling, yaitu pengambilan sampel dengan tidak memberi peluang yang sama pada setiap individu dalam populasi untuk dijadikan sampel(Sekaran 2009, 276). Teknik non-probability sampling yang digunakan adalah judgemental sampling (purposive sample), yaitu sampel yang menentukan kriteria khusus yang harus dipenuhi untuk dapat berpartisipasi dalam penelitian. Populasi dalam penelitian ini adalah seluruh karyawan PT Asuransi Bintang yang berjumlah 178 karyawan. Menurut Hair et al (2009, 166) dalam penentuan jumlah sampel, aturan yang secara umum berlaku adalah perbandingan antara lima observasi untuk setiap satu variabel independen. Penelitian ini memiliki 17 indikator penelitian, jadi kebutuhan akan sampel minimal adalah sebesar 85 sampel.

\section{Analisis Data}


Penelitian menggunakan analisis regresi berganda, namun demikian untuk memastikan bahwa data yang digunakan adalah data yang baik maka perlu memenuhi asumsi distribusi data yang normal, tidak terjadinya tumpang tindih data, data yang sudah andal, dan data yang layak untuk dianalisis lebih lanjut. Untuk menganalisis data digunakan alat ukur untuk mengetahui tingkat reliabilitas dan vadilitas data.Uji Reliabilitas atau keandalanakan digunakan Cronbach alpha. Metode ini merupakan metode yang paling umum digunakan dalam menguji tingkat keandalan (Sekaran 2013, 205). Semakin koefisien mendekati satu maka pertanyaan dalam kuesioner dianggap memiliki keandalan yang tinggi. Batas yang dikategorikan baik adalah jika koefisien di atas 0,7 (Sekaran 2013, 311).Validitas dapat tercapai melalui validitas konverjen dan validitas diskriminan. Validitas konverjen terjadi ketika instrumen-instrumen yang diukur melalui suatu konsep memiliki tingkat korelasi yang tinggi. Sedangkan, validitas diskriminan terjadi ketika pengukuran variabel memiliki korelasi yang rendah dengan variabel lainnya (Sekaran 2013, 207). Validitas konverjen dapat dinilai dengan menggunakan faktor analisis. Tingkat loading significant pada faktor analisis dapat dilihat berdasarkan jumlah sampel penelitian. Sampel yang digunakan pada pengujian pra analisis adalah sebesar 50 sampel, maka nilai muatan yang signifikan adalah sebesar 0,75. Sedangkan pada penelitian aktual sampel yang digunakan sebesar 103 sampel. Dengan demikian, nilai muatan faktor yang signifikan adalah lebih besar sama dengan 0,55. Korelasi dalam validitas diskriminan dapat dilihat berdasarkan korelasi Spearman. Korelasi Spearman dipakai untuk melihat korelasi yang terjadi dalam validitas diskriminan bagi data yang merupakan data interval. Karena penelitian ini menggunakan data interval, maka korelasi Spearman dapat digunakan. Selain itu, validitas diskriminan hanya akan tercapai apabila nilai korelasi yang diperoleh dari hasil analisis tidak melebihi angka 0,75 (Sekaran 2013, 315). Dalam penelitian ini uji korelasi dilakukan untuk melihat terjadi atau tidaknya multikolinearitas terhadap variabel yang diuji. Multikolinearitas akan terjadi apabila adanya sebuah variabel yang dapat dijelaskan oleh variabel lain dan memiliki nilai korelasi di atas 0,80. Menurut Hair et al. $(2009,89)$ multikolinearitas dapat terjadi jika sebuah variabel telah dijelaskan oleh variabel lainnya dan memiliki korelasi 
yang tinggi.Metode analisis yang digunakan dalam penelitian ini adalah metode analisis regresi berganda. Alasan penggunaaan metode analisis regresi berganda karena hasil dari metode ini bisa digunakan untuk memprediksi suatu gejala dan menjelaskan suatu gejala yang muncul (Hair et al. 2009, 223). Beberapamacam asumsi analisis regresi berupa asumsi klasik yang dilakukan terdiri dari Autokorelasi, Multikolinearitas,Heteroskedastisitas, Normalitas.

\section{Definisi Konseptual dan Variabel}

Variabel yang ada dalam penelitian dapat dijelaskan melalui definisi konseptual dan definisi operasional. Pengertian konseptual adalah arti akademik atau arti universal dari sebuah kata atau kelompok kata yang dapat dimengerti oleh semua orang. Sedangkan, definisi operasional adalah definisi yang dipakai untuk menjelaskan atau menerjemahkan istilah atau konsep dengan lebih jelas.

Tabel 1. Definisi Konseptual dan Operasional Variabel

\begin{tabular}{|c|c|c|c|c|c|}
\hline Variabel & Konseptual & & Operasional & Skala & Sumber \\
\hline \multirow[t]{5}{*}{ Kepemimpinan } & \multirow{5}{*}{$\begin{array}{l}\text { sebagai kemampuan } \\
\text { mendorong sejumlah } \\
\text { orang (dua orang } \\
\text { atau lebih) agar } \\
\text { bekerja sama dalam } \\
\text { melaksanakan } \\
\text { kegiatan-kegiatan } \\
\text { yang terarah pada } \\
\text { tujuan } \\
\text { bersama. (Hill dan } \\
\text { Caroll 2001) }\end{array}$} & 1 & $\begin{array}{l}\text { Atasan mampu berkomunikasi } \\
\text { secara efektif }\end{array}$ & \multirow[t]{5}{*}{ Likert } & \multirow{5}{*}{$\begin{array}{l}\text { Swierczek } \\
\text { dan } \\
\text { Hirsch } \\
2000\end{array}$} \\
\hline & & 2 & $\begin{array}{l}\text { Atasan selalu mendukung } \\
\text { karyawan untuk } \\
\text { meningkatkan kualitas kerja }\end{array}$ & & \\
\hline & & 3 & $\begin{array}{l}\text { Atasan mampu menyusun } \\
\text { rencana jangka panjang yang } \\
\text { baik sesuai visi perusahaan }\end{array}$ & & \\
\hline & & 4 & $\begin{array}{l}\text { Atasan selalu memberikan } \\
\text { kesempatan pada } \\
\text { karyawannya untuk mengikuti } \\
\text { pelatihan dan pengembangan } \\
\text { diri }\end{array}$ & & \\
\hline & & 5 & $\begin{array}{l}\text { Atasan selalu membina } \\
\text { hubungan baik dengan } \\
\text { bawahnnya }\end{array}$ & & \\
\hline \multirow[t]{3}{*}{ Motivasi } & \multirow{3}{*}{$\begin{array}{l}\text { pemberian daya } \\
\text { penggerak yang } \\
\text { menciptakan } \\
\text { kegairahan } \\
\text { seseorang agar } \\
\text { mereka mau bekerja }\end{array}$} & 1 & $\begin{array}{l}\text { Gaji atau upah yang diberikan } \\
\text { sesuai dengan harapan }\end{array}$ & \multirow[t]{3}{*}{ Likert } & \multirow{3}{*}{$\begin{array}{l}\text { Kinicki } \\
\text { dan } \\
\text { Kreitner } \\
2011\end{array}$} \\
\hline & & 2 & Perasaan senang saat bekerja & & \\
\hline & & 3 & $\begin{array}{l}\text { Mendapat kepercayaan penuh } \\
\text { dalam melaksanakan }\end{array}$ & & \\
\hline
\end{tabular}




\begin{tabular}{|c|c|c|c|c|c|}
\hline & \multirow{4}{*}{$\begin{array}{l}\text { sama, bekerja } \\
\text { efektif dan } \\
\text { terintegrasi dengan } \\
\text { segala daya } \\
\text { upayanya untuk } \\
\text { mencapai kepuasan } \\
\text { (Hasibuan 2000, } \\
142 \text { ). }\end{array}$} & & pekerjaan & & \\
\hline & & 4 & $\begin{array}{l}\text { Pekerjaan yang dilakukan } \\
\text { memiliki kontribusi penting } \\
\text { pada pencapaian tujuan } \\
\text { Perusahaan }\end{array}$ & & \\
\hline & & 5 & $\begin{array}{l}\text { Pekerjaan mampu menjadi } \\
\text { sarana untuk mengekspresikan } \\
\text { diri }\end{array}$ & & \\
\hline & & 6 & $\begin{array}{l}\text { Kinerja atau prestasi dinilai } \\
\text { secara obyektif }\end{array}$ & & \\
\hline \multirow[t]{6}{*}{$\begin{array}{l}\text { Kinerja } \\
\text { karyawan }\end{array}$} & \multirow{6}{*}{$\begin{array}{l}\text { Prestasi kerja atau } \\
\text { kinerja adalah } \\
\text { hasil kerja yang } \\
\text { dicapai oleh seorang } \\
\text { pegawai dalam } \\
\text { melaksanakan tugas } \\
\text { yang dibebankan } \\
\text { kepadanya (Saidi } \\
\text { 2002). }\end{array}$} & 1 & $\begin{array}{l}\text { Selalu memberikan masukan } \\
\text { yang baik pada atasan untuk } \\
\text { penyelesaian pekerjaan }\end{array}$ & \multirow[t]{6}{*}{ Likert } & \multirow[t]{6}{*}{$\begin{array}{l}\text { Siagian } \\
2003\end{array}$} \\
\hline & & 2 & $\begin{array}{l}\text { Hasil kerja sesuai dengan } \\
\text { perintah yang diberikan oleh } \\
\text { atasan }\end{array}$ & & \\
\hline & & 3 & $\begin{array}{l}\text { Selalu hadir tepat waktu } \\
\text { dalam bekerja }\end{array}$ & & \\
\hline & & 4 & $\begin{array}{l}\text { Mudah beradaptasi dengan } \\
\text { lingkungan kerja }\end{array}$ & & \\
\hline & & 5 & $\begin{array}{l}\text { Mampu mengerjakan dengan } \\
\text { baik penugasan dari pekerjaan } \\
\text { yang baru }\end{array}$ & & \\
\hline & & 6 & $\begin{array}{l}\text { Penugasan yang diberikan } \\
\text { selalu terselesaikan tepat } \\
\text { waktu }\end{array}$ & & \\
\hline
\end{tabular}

\section{Hasil dan Pembahasan}

\section{Profil Responden.}

Berdasarkan jenis kelamin mayoritas responden yang dilibatkan dalam penelitian ini adalah pria, sebanyak 68 responden atau 66\%.Sedangkan responden wanita sebanyak 35 responden atau sebesar 34\%.Artinya mayoritas karyawan yang bekerja di PT Asuransi Bintang adalah pria. Berdasarkan kelompok usia, 36 responden atau $35 \%$ berusia antara 21 hingga 30 tahun, 58 responden atau 56,3\% berusia antara 31 hingga 40 tahun, dan 9 responden atau 8,7\% berusia antara 41 hingga 50 tahun. Berdasarkan lamanya bekerja, 15 responden atau 14,56\% bekerja kurang dari 1 tahun, 36 responden atau 34,95\% bekerja selama $1-2$ tahun, 32 
responden atau 31,06\% bekerja selama 2 - 3 tahun, 20 responden atau 19,43\% sudah bekerja lebih dari 3 tahun. Berdasarkan pendidikan terakhir, 11 responden atau 10,67\% pendidikan terakhir SMU, 20 responden atau 19,41\% pendidikan terakhir Akademi (D1/D2/D3), 68 responden atau 66,01\% pendidikan terakhir Sarjana (S1), 4 responden atau 3,91\% pendidikan terakhir Pasca Sarjana (S2). Dari hasil profil responden dapat dikaitkan terhadap masalah penelitian bahwa mengapa pria lebih banyak daripada wanita, dengan usia 31-40 tahun, dan mayoritas pendidikan terakhir S1. Dapat dilihat bahwa karyawan pria dengan usia yang cukup matang dan tingkat pendidikan yang cukup baik sangat dominan pada PT Asuransi Bintang yang seharusnya untuk sebuah perusahaan asuransi diminati juga oleh wanita pekerja pada umumnya. Dari segi lamanya bekerja dapat terlihat cukup banyak karyawan yang sudah bekerja selama lebih dari 2 tahun. Dari segi pendapatan dapat dilihat bahwa jenis kelamin, usia, lama bekerja, pendidikan terakhir tidak berpengaruh pada pendapatan. Karena pendapatan bergantung pada semakin banyak nasabah yang didapat oleh karyawan atau sales. Semakin banyak nasabah yang didapat maka akan berpengaruh pada pendapatan dan insentif yang diterima oleh karyawan.

\section{Hasil Pengujian Reliabilitas Pra Analisis}

Hasil pengujian reliabilitas menunjukkan bahwa nilai Cronbach alpha faktor kepempimpinan, motivasi, dan kinerja karyawan lebih besar dari 0,7 yang berarti data yang terkumpul pada tahap pra analisis sudah dapat diandalkan dalam mengumpulkan informasi yang dibutuhkan. Selain menggunakan nilai Cronbach alpha, dapat juga mempertimbangkan nilai corrected item-total correlation yang menurut Hair et al. $(2009,118)$ batasan minimal nilai tersebut adalah sebesar 0,5. Apabila nilai setiap indikator tersebut lebih besar dari 0,5 , maka indikator yang merupakan pertanyaan dalam kuesioner sudah dapat diandalkan. 
Tabel 2. Hasil Pengujian Validitas Pra Analisis

\begin{tabular}{|c|c|c|c|}
\hline Faktor & Indikator & $\begin{array}{c}\text { Cronbach } \\
\text { alpha }\end{array}$ & Corrected item_total correlation \\
\hline \multirow{4}{*}{ Kepemimpinan } & KE1 & \multirow{4}{*}{0,865} & 0,734 \\
\hline & KE2 & & 0,731 \\
\hline & KE3 & & 0,655 \\
\hline & KE4 & & 0,761 \\
\hline \multirow{5}{*}{ Motivasi } & MO1 & \multirow{5}{*}{0,906} & 0,842 \\
\hline & $\mathrm{MO} 2$ & & 0,675 \\
\hline & MO3 & & 0,759 \\
\hline & MO4 & & 0,729 \\
\hline & MO5 & & 0,819 \\
\hline \multirow{4}{*}{ Kinerja Karyawan } & KK1 & \multirow{4}{*}{0,883} & 0,751 \\
\hline & KK2 & & 0,797 \\
\hline & KK3 & & 0,761 \\
\hline & KK4 & & 0,684 \\
\hline
\end{tabular}

Semua indikator penelitian sudah valid karena sudah terkumpul pada faktor atau komponennya masing-masing. Selain setiap indikator sudah terkumpul pada

faktornya masing-masing, setiap indikator telah memiliki nilai yang lebih besar dari 0,75, dimana menurut Hair et al. (2009, 112) muatan faktor yang signifikan untuk jumlah sampel 50 adalah lebih besar atau sama dengan 0,75. Apabila nilai muatan faktor indikator tersebut kurang dari 0,75 pada jumlah sampel 50 maka indikator tersebut tidaklah signifikan atau layak dalam pengukurannya.

Tabel 3. Hasil Uji Validitas Pra Analisis

\begin{tabular}{|l|c|c|c|}
\hline & \multicolumn{3}{|c|}{ Component } \\
\hline & $\mathbf{1}$ & $\mathbf{2}$ & $\mathbf{3}$ \\
\hline Kepemimpinan1 & & & .817 \\
Kepemimpinan2 & & & .850 \\
Kepemimpinan3 & & & .839 \\
Kepemimpinan4 & & & .834 \\
Motivasi1 & .873 & & \\
Motivasi2 & .806 & & \\
Motivasi3 & .787 & & \\
Motivasi4 & .765 & & \\
Motivasi5 & .859 & & \\
Kinerja Karyawan1 & & .809 & \\
Kinerja Karyawan2 & & .846 & \\
Kinerja Karyawan3 & & .826 & \\
\hline
\end{tabular}




\begin{tabular}{|l|l|l|l|}
\hline Kinerja Karyawan4 & & .814 & \\
\hline Sumber: Data Diolah
\end{tabular}

\section{Hasil Pengujian Reliabilitas Aktual}

Nilai Cronbach alpha lebih besar dari 0,7 sehingga hasil pengujian dapat dikategorikan baik dan dapat disimpulkan bahwa data yang diperoleh memiliki tingkat keandalan yang tinggi atau baik (Sekaran 2013, 311). Sedangkan nilai corrected item-total correlation terendah dari hasil pengujian adalah sebesar 0,533 pada indikator MO1 dan nilai corrected item-total correlation tertinggi adalah sebesar 0,678 pada indikator MO5.

Tabel 4. Hasil Uji Reliabilitas Penelitian Aktual

\begin{tabular}{|c|c|c|c|}
\hline Faktor & Indikator & $\begin{array}{c}\text { Cronbach } \\
\text { alpha }\end{array}$ & $\begin{array}{c}\text { Corrected item_total } \\
\text { correlation }\end{array}$ \\
\hline \multirow{4}{*}{ Kepemimpinan } & KE1 & \multirow{4}{*}{0,798} & 0,609 \\
\hline & KE2 & & 0,562 \\
\hline & KE3 & & 0,647 \\
\hline & KE4 & & 0,661 \\
\hline \multirow{5}{*}{ Motivasi } & MO1 & \multirow{5}{*}{0,811} & 0,533 \\
\hline & MO2 & & 0,639 \\
\hline & $\mathrm{MO} 3$ & & 0,605 \\
\hline & MO4 & & 0,566 \\
\hline & MO5 & & 0,678 \\
\hline \multirow{4}{*}{$\begin{array}{l}\text { Kinerja } \\
\text { Karyawan }\end{array}$} & KK1 & \multirow{4}{*}{0,813} & 0,624 \\
\hline & KK2 & & 0,651 \\
\hline & KK3 & & 0,613 \\
\hline & KK4 & & 0,645 \\
\hline
\end{tabular}

Sumber: Data Diolah

\section{Hasil Pengujian Validitas Penelitian Aktual}

Hasil pengujian validitas menggunakan exploratory factor analysis menunjukkan bahwa setiap indikator penelitian telah valid karena sudah terkumpul pada faktornya masing-masing, dimana nilai muatan faktor setiap indikator lebih besar dari 0,55. Menurut Hair et al. $(2009,112)$ nilai muatan faktor yang dapat dinyatakan valid untuk jumlah sampel 103 adalah lebih besar atau sama dengan 0,55 . 
Tabel 5. Hasil Uji Validitas Penelitian Aktual

\begin{tabular}{|l|c|c|c|}
\hline & \multicolumn{3}{|c|}{ Component } \\
\hline & $\mathbf{1}$ & $\mathbf{2}$ & $\mathbf{3}$ \\
\hline Kepemimpinan1 & & .824 & \\
Kepemimpinan2 & & .722 & \\
Kepemimpinan3 & & .744 & \\
Kepemimpinan4 & .674 & .763 & \\
Motivasi1 & .778 & & \\
Motivasi2 & .771 & & .831 \\
Motivasi3 & .727 & & .695 \\
Motivasi4 & .794 & & .762 \\
Motivasi5 & & & \\
Kinerja Karyawan1 & & & \\
Kinerja Karyawan2 & & & \\
Kinerja Karyawan3 & & \\
Kinerja Karyawan4 & & \\
Sumber: Data Diolah
\end{tabular}

\section{Hasil Uji Asumsi Klasik}

\section{Autokorelasi}

Autocorrelation dilakukan dengan uji Durbin-Watson karena jumlah sampel yang digunakan relatif besar.Nilai dari hasil uji Durbin-Watson diperoleh dari output analisis regresi berganda, yaitu Tabel Model Summary ${ }^{b}$. Nilai Durbin-Watson yang diperoleh dari analisis regresi adalah sebesar 2,049. Berdasarkan Tabel DurbinWatson dengan nilai signifikansi 0,05 dan jumlah sampel (n) sebesar 103, dimana $\mathrm{k}$ $=2$ (jumlah variabel independen) diketahui nilai dL sebesar 1,73 dan dU 1,81. Nilai hasil analisis regresi berada diantara 1,81 (dU) sampai dengan 2,19 (4-dU), maka dapat dinyatakan bahwa tidak terjadi autocorrelation antara variabel independen dengan variabel dependen.

Tabel 6. Hasil Uji Durbin-Watson

\begin{tabular}{|c|c|}
\hline Model & Durbin-Watson \\
\hline 1 & 2.049 \\
& \\
\hline & Sumber: Data Diolah
\end{tabular}

\section{Multikolinearitas}

Hasil analisis menunjukkan bahwa nilai tolerance untuk setiap faktor, yaitu kepemimpinan dan motivasi terhadap kinerja karyawan memiliki nilai lebih besar 
dari 0,1 dan nilai VIF setiap faktor tersebut kurang dari 10, sehingga dapat disimpulkan bahwa tidak terjadi multicollinearity pada seluruh data yang dianalisis.

Tabel 7. Hasil Uji Multicollinearity

\begin{tabular}{|c|c|c|}
\hline \multirow{2}{*}{} & \multicolumn{2}{|c|}{ Collinearity Statistics } \\
\cline { 2 - 3 } & Tolerance & VIF \\
\hline (Constant) & & \\
Kepemimpinan & .955 & 1.047 \\
Motivasi & .955 & 1.047 \\
\hline
\end{tabular}

Sumber: Data Diolah

\section{Heteroskedastisitas}

Pengujian heteroscedastic dilakukan menggunakan grafik, yaitu graphical test of equal variance.Graphical test of equal variance menunjukkan bahwa data menyebar secara tidak acak dan mengikuti pola tertentu untuk masing-masing variabel, sehingga dapat dikatakan tidak terjadi heteroscedastic.

\section{Gambar 2. Uji Heteroskedastisitas}

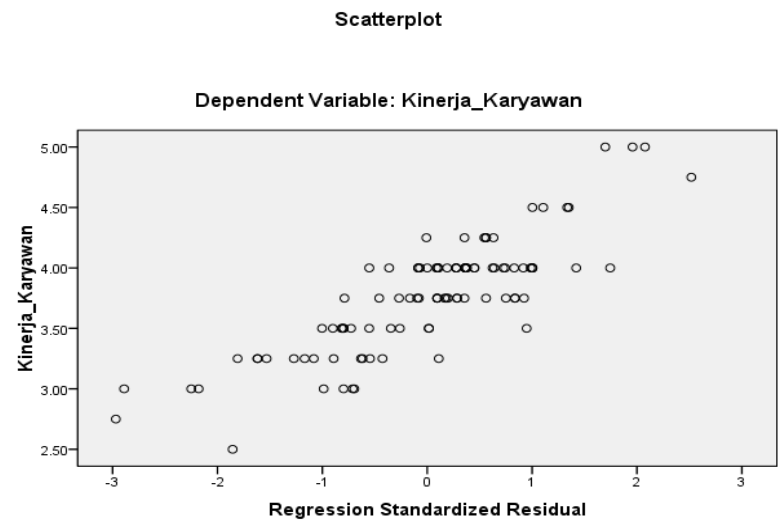

Sumber: Data Diolah

\section{Normalitas}

Pengujian menggunakan grafik Normal P-P Plot.Grafik Normal P-P Plot of Regression Standardized Residual menunjukkan bahwa penyebaran data disekitar garis uji berkelompok dengan mengarah ke kanan atas.Tidak ada data yang terletak 
jauh dari sebaran data, dengan demikian data yang dianalisis dapat dikatakan berdistribusi normal.Dapat dipastikan bahwa seluruh data yang dianalisis berdistribusi normal dan dapat di analisis lebih lanjut menggunakan analisis regresi berganda

\section{Gambar 3. Normal P-P Plot of Regression Standardized Residual}

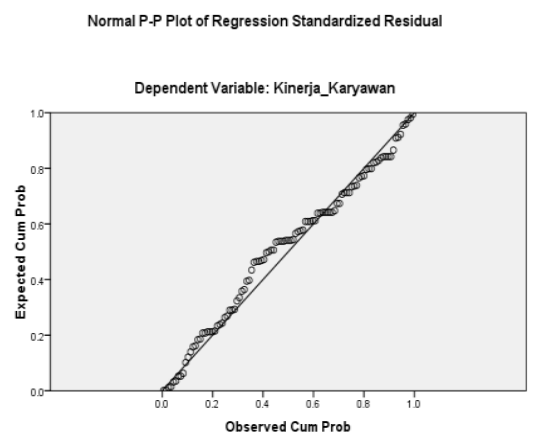

Sumber: Data Diolah

\section{Pembahasan Analisis Regresi Berganda}

\section{F-test}

Uji F-statistik dilakukan untuk mengetahui apakah ada hubungan atau pengaruh yang signifikan pada faktor kepemimpinan dan motivasi terhadap kinerja karyawan.

Tabel 8. Hasil Uji F-Statistik

\begin{tabular}{|l|r|r|r|r|}
\hline \multicolumn{1}{|l|}{ Model } & Sum of Squares & Df & Mean Square & F \\
\hline Regression & 6.422 & 2 & 3.211 & 20.500 \\
Residual & 15.664 & 100 & .157 & \\
Total & 22.086 & 102 & & \\
\hline
\end{tabular}

Sumber: Data Diolah

Dengan variabel dependen kinerja karyawan dan variabel independen kepemimpinan dan motivasi dapat diketahui bahwa hasil uji analysis of variance (anova) menunjukkan nilai F-statistik sebesar 20,500 dengan tingkat signifikansi 0,000.Dengan berpedoman pada nilai F-tabel untuk tingkat keyakinan (level of confidence) penelitian sebesar 95\% diperoleh nilai F-tabel sebesar 2,418.Maka nilai F-statistik yang diperoleh dari hasil analisis lebih besar dari nilai F-tabel yang berarti 
bahwa faktor kepemimpinan dan motivasi secara bersama-sama berpengaruh signifikan dari terhadap kinerja karyawan. Oleh karena $\mathrm{F}$ hitung $>\mathrm{F}$ tabel $=20,5$ maka hipotesis alternative (H1) diterima atau didukung, sehingga model regresi dapat dipakai untuk memprediksi kinerja karyawan, atau dapat dikatakan, kepemimpinan dan motivasi secara bersama-sama berpengaruh terhadap kinerja karyawan.

\section{R Square}

Setelah diketahui adanya pengaruh yang signifikan dari variabel independen terhadap variabel dependen maka digunakan uji $R$ square untuk mengetahui seberapa besar variabel independen dapat menjelaskan perubahan pada variabel dependen.

Tabel 9. Hasil Uji R Square

\begin{tabular}{|r|r|r|r|r|}
\hline Model & \multicolumn{1}{|c|}{$\mathrm{R}$} & R Square & \multicolumn{1}{c|}{$\begin{array}{c}\text { Adjusted R } \\
\text { Square }\end{array}$} & $\begin{array}{l}\text { Std. Error of the } \\
\text { Estimate }\end{array}$ \\
\hline 1 & .539 & .291 & .277 & .39578 \\
\hline
\end{tabular}

Sumber: Data Diolah

Dengan variabel dependen kinerja karyawan dan variabel independen kepemimpinan dan motivasi, nilai $R$ square yang diperoleh adalah sebesar 0,291 yang berarti bahwa perubahan pada faktor kinerja karyawan dapat dijelaskan oleh faktor kepemimpinan dan faktor motivasi sebesar 29,1\%, sedangkan sisanya sebesar 70,9\% dijelaskan oleh faktor-faktor lain diluar model penelitian yang digunakan, seperti misalnya tekanan kerja, tekanan lingkungan, tingkat pendidikan, kecerdasan, gaya hidup, lokasi tempat tinggal, motivasi dalam bentuk reward, budaya organisasi, segmen dan kelas sosial.

\section{T-Test}

Sebelum menginterpretasikan besarnya nilai koesien regresi yang diperoleh dari analisis regresi berganda, perlu terlebih dahulu mengetahui tingkat signifikansi dari hubungan masing-masing variabel independen terhadap variabel dependen. 
Tabel 10 Hasil Uji T-Statistik

\begin{tabular}{|l|r|r|r|r|r|}
\hline & \multicolumn{2}{|c|}{$\begin{array}{c}\text { Unstandardized } \\
\text { Coefficients }\end{array}$} & $\begin{array}{c}\text { Standardized } \\
\text { Coefficients }\end{array}$ & & \\
\cline { 2 - 5 } & \multicolumn{1}{|c|}{ B } & Std. Error & Beta & & \\
\hline (Constant) & 1.454 & .388 & & 3.744 & .000 \\
Kepemimpinan & .438 & .080 & .472 & 5.471 & .000 \\
Motivasi & .172 & .082 & .180 & 2.088 & .039 \\
\hline
\end{tabular}

Sumber: Data Diolah

Untuk mengetahui tingkat signifikansi dari korelasi masing-masing variabel maka hasil uji t-statistik menjadi pedoman ada tidaknya korelasi yang signifikan dari hubungan yang terbentuk.Selain nilai t-statistik dapat pula digunakan nilai signifikansi atau probabilitas (Sig.).Besar nilai t-statistik yang menunjukkannya ada korelasi yang signifikan harus lebih besar dari t-tabel yaitu 2,000. Besaran tersebut ditentukan berdasarkan tingkat keyakinan penelitian sebesar 95\% dengan tingkat signifikansi 5\% dan jumlah sampel sebesar 103 responden. Sedangkan nilai signifikansi yang menunjukkan adanya korelasi yang signifikan adalah lebih kecil atau sama dengan 0,05. Tabel 10 menunjukkan nilai-nilai korelasi antara setiap variabel independen dengan variabel dependen, yaitu variabel kinerja karyawan. Dari nilai-nilai korelasi tersebut dapat dibuat persamaan regresi sebagai berikut:

Kinerja Karyawan $=1,454+0,438$ kepemimpinan $+0,172$ motivasi.

Berdasarkan Tabel 4.10 maka dapat dinterpretasikan bahwa hubungan antara kepemimpinan dan kinerja karyawan adalah signifikan karena memiliki nilai tstatistik yang lebih besar dari 2,000 dan nilai signifikansi yang lebih kecil dari 0,05, yaitu nilai t-statistik sebesar 5,471 dan nilai signifikansi 0,000.

Koefisien regresi antara kepemimpinan dan kinerja karyawan adalah positif yang berarti bahwa apabila nilai kepemimpinan meningkat maka akan turut meningkatkan kinerja karyawan. Koefisien regresi kepemimpinan dan kinerja karyawan sebesar 0,438 yang berarti kenaikan kepemimpinan sebesar satu satuan unit akan meningkatkan kinerja karyawan pelanggan sebesar 0,438 atau dapat dikatakan bahwa kepemimpinan berpengaruh secara signifikan terhadap kinerja karyawan sebesar $(0,4382)$ 19,2\%. Hubungan antara motivasi dan kinerja karyawan adalah 
signifikan dengan nilai t-statistik yang lebih besar dari 1,96 dan nilai signifikansi yang lebih kecil dari 0,05 yaitu nilai t-statistik sebesar 2,088 dan nilai signifikansi 0,000. Koefisien regresi antara motivasi dan kinerja karyawan adalah positif yang berarti bahwa apabila nilai motivasi meningkat maka akan turut meningkatkan kinerja karyawan. Koefisien regresi motivasi dan kinerja karyawan sebesar 0,172 yang berarti kenaikan motivasi sebesar satu satuan unit akan meningkatkan kinerja karyawan sebesar 0,172 atau dapat dikatakan bahwa motivasi berpengaruh positif dan signifikan terhadap kinerja karyawan sebesar $\left(0,172^{2}\right) 3 \%$. Berdasarkan hasil uji F-Test, dapat diketahui bahwa faktor kepemimpinan dan faktor motivasi secara bersama-sama berpengaruh positif dan signifikan terhadap kinerja karyawan PT Asuransi Bintang. Nilai pengaruh dari faktor kepemimpinan dan faktor motivasi terhadap kinerja karyawan adalah sebesar $29,1 \%$.

\section{Pembahasan Intepretasi Manajerial}

\section{Intepretasi Persepsi Kepemimpinan Terhadap Kinerja Karyawan}

Faktor kepemimpinan merupakan faktor yang dominan memiliki persepsi signifikan terhadap kinerja karyawan di PT Asuransi Bintang. Persepsi yang dihasilkan faktor kepemimpinan adalah sebesar 19,2\% terhadap kinerja karyawan. Ini dapat dijelaskan bahwa dengan kepemimpinan ber karakter yang memberikan dorongan kerja keras yang tinggi, memiliki kemauan yang kuat untuk memimpin orang lain, membangun kepercayaan antara pemimpin dan karyawan, percaya diri dan cerdas maka pemimpin akan mendapat memacu karyawan untuk dapat bekerja sama dalam melaksanakan kegiatan-kegiatan yang terarah pada tujuan bersama. Dalam hal ini PT Asuransi Bintang secara rutin mengikutsertakan karyawannya dalam seminar maupun pelatihan yang dapat meningkatkan kemampuan, kepercayaan diri, dan kecerdasan karyawan perusahaan asuransi. Tipe kepemimpinan yang baik menurut Burns (2013) adalah transaksional dengan memperhatikan sasaran dalam perusahaan dan bagaimana sasaran itu bisa terwujud dengansistem reward dan punishment, dan transformasional dengan menekankan pada gambaran yang besar terhadap pekerjaan dan mampu memotivasi karyawan untuk bekerja dengan lebih baik. Dengan atasan mau ikut turun langsung ke 
lapangan, dalam arti atasan juga memperkenalkan produk asuransi pada calon nasabah maka hal ini akan memotivasi karyawan di bawahnya untuk turut dan bahkan lebih giat dalam memperkenalkan produk asuransi pada calon nasabah. Dan dengan gaya kepemimpinan yang baik maka pemimpin akan dapat mempengaruhi karyawan untuk dapat bekerja dengan baik dalam mencapai sasaran organisasi. Atasan juga perlu membina hubungan yang baik dengan bawahan dan membagi pengalaman mengenai dunia asuransi agar bawahan dapat mengikuti jejak positif atasan nya sehingga bila pernah terjadi kesalahan tidak terulang lagi. Berdasarkan hasil tersebut maka faktor kepemimpinan di PT Asuransi Bintang merupakan faktor yang perlu mendapatkan perhatian secara khusus dari manajemen PT Asuransi Bintang dalam mempengaruhi tingkat kinerja karyawan di perusahaan tersebut.

\section{Intepretasi Persepsi Motivasi Terhadap Kinerja Karyawan}

Sedangkan faktor kedua yang memiliki persepsi terhadap kinerja karyawan adalah faktor motivasi dengan kontribusi pengaruh sebesar 3\%. Hal ini dapat dijelaskan melalui motivasi yang diberikan oleh atasan melalui kinerja atau prestasi yang dinilai secara obyektif dan tingkat gaji atau upah yang diberikan sesuai dengan harapan akan dapat mempengaruhi kinerja karyawan. Menurut prinsip Penetapan Target (Goal setting theory), karyawan akan termotivasi untuk mencapai hasil kerja yang lebih tinggi jika mereka memiliki target yang spesifik (Locke \& Latham, dalam Donovan, 2001). Teori ini berkesimpulan bahwa penetapan suatu tujuan tidak hanya berpengaruh pada pekerjaan saja tetapi juga merangsang karyawan untuk mencari atau menggunakan metode kerja yang paling efektif.Locke juga berpendapat bahwa melibatkan para karyawan dalam menetapkan tujuan dapat menumbuhkan motivasi kerja dan pencapaian prestasi kerja maksimal.Teori berikutnya adalah teori B.F. Skinner.Adalah tugas manajer untuk menciptakan suatu kondisi yang dapat memberikan rasa aman, nyaman, memberikan rewards/punishment, memberikan reinforcer sehingga mendorong karyawan untuk berperilaku seperti yang diharapkan.Negative Reinforcement, misalnya pemberian SP 1 untuk karyawan yang datang terlambat lebih dari 5 kali berturut-turut dalam waktu 1 bulan, menegur karyawan yang pulang sebelum jam 5 sore. Punishment, misalnya memindahkan karyawan yang tidak dapat memenuhi target, dan 
mendorong karyawan yang dianggap tidak capable agar mengundurkan diri. Punishment ini bertujuan untuk menghilangkan perilaku yang tidak disukai. Termasuk juga menghilangkan karyawan yang dia anggap hanya akan menjadi beban perusahaan. Positive Reinforcements, berupa rewards atau kenaikan jabatan untuk karyawan yang dapat mencapai tantangan yang dia tetapkan. Rewards ini bertujuan untuk memotivasi orang-orang yang dinilai bagus untuk terus bekerja keras untuk dapat mencapai target yang ditetapkan. Sebagai gantinya karyawan tersebut harus rela pulang diatas jam 5 sore setiap hari karena beratnya target yang ditetapkan. Karyawan juga termotivasi jika mendapat kepercayaan penuh dari atasan dalam menjalankan pekerjaan dan jika pekerjaan yang dilakukan oleh karyawan tersebut memiliki kontribusi penting pada pencapaian tujuan perusahaan. Pada penelitian sebelumnya yang dilakukan oleh Wahyuddin dan Djumino (2002) diperoleh hasil yang sama dengan penelitian ini, dimana dijabarkan bahwa faktor kepemimpinan dan faktor motivasi memiliki pengaruh terhadap kinerja karyawan, baik secara sendiri-sendiri maupun secara bersama-sama.

\section{Kesimpulan dan Saran}

1. Kepemimpinan berpersepsi positif yang signifikan terhadap kinerja karyawan PT Asuransi Bintang. Ini dikarenakan penelitian membuktikan karyawan membutuhkan karakter kepemimpinan yang mendorong kerja keras yang tinggi mempunyai keinginan besar untuk berhasil ambisius dan inisiatif. Karyawan juga membutuhkan karakter pemimpin yang mampu mentransformasikan kecerdasan, kejujuran, dan kepercayaan diri kepada karyawan dalam bekerja. Karyawan juga membutuhkan gaya kepemimpinan dari atasannya yang mampu memotivasi dan memacu kinerja mereka dengan berbagi pengalaman dan terbinanya hubungan yang baik antara atasan dan bawahan.

2. Motivasi berpersepsi positif yang signifikan terhadap kinerja karyawan PT Asuransi Bintang. Ini dikarenakan penelitian membuktikan bahwa karyawan membutuhkan penetapan tujuan yang ingin dicapai perusahaan (goal setting). Sehingga dengan memiliki tujuan yang jelas maka karyawan akan memacu dirinya untuk prestasi kerja yang maksimal agar mencapai tujuan tersebut. Tentu saja untuk memacu karyawan dibutuhkan suatu sistem, sebagai contoh 
melalui Negative Reinforcement dan Positive Reinforcement dengan reward dan punishment yang jelas.

3. Dan pada akhirnya kepemimpinan dan motivasi secara bersama-sama berpengaruh signifikan terhadap Kinerja karyawan PT Asuransi Bintang.

Sesuai dari hasil uji multiple regression yang ada memiliki nilai signifikansi > 0,05 .

Dalam indikator-indikator kepemimpinan, indikator yang paling mempengaruhi karyawan di dalam perusahaan tersebut adalah indikator KE4, dimana indikator ini menggambarkan atasan selalu memberikan kesempatan kepada karyawannya untuk mengikuti pelatihan dan pengembangan diri, yang dapat dilihat dari karyawan diikutsertakan pada seminar perusahaan asuransi dan pelatihan pengembangan diri secara rutin.

4. Kemudian pada variabel motivasi, indikator yang paling berpengaruh adalah indikator MO5 yang menjelaskan bahwa kinerja atau prestasi yang dihasilkan oleh karyawan dinilai secara obyektif oleh atasan, yang artinya atasan memberikan penilaian (performance appraisal) secara berkala dan memberikan perbaikan dan masukan terhadap kinerja karyawan tersebut secara obyektif. Salah satu faktor yang sering dinilai berkontribusi pada motivasi adalah kepemimpinan. Dimana kepemimpinan transformasional kerap kali dianggap sebagai model kepemimpinan yang paling efektif. Kepemimpinan transformasional yang dimaksud memiliki cirri-ciri karismatik, inspirasional, menstimulasi intelektual dan perhatian kepada individu (Burns, 2013). Untuk variabel dependen, indikator kinerja karyawan $\mathrm{KK} 3$, dimana indikator ini menjelaskan bahwa karyawan selalu hadir tepat waktu, yang artinya perusahaan secara disiplin menerapkan jam kerja karyawan tepat waktu dengan menggunakan teknologi finger print. Dengan karyawan hadir tepat waktu maka tugas dan pekerjaan yang diberikan atasan kepada karyawan dapat terselesaikan dengan baik dan tepat waktu.

\section{Saran Untuk PT Asuransi Bintang}


Untuk PT Asuransi Bintang disarankan agar perusahaan mengadakan pelatihan-pelatihan kepemimpinan pada setiap kepala divisi, terutama yang berhubungan dengan dimensi inspirasional (agar atasan dapat memacu antusiasme karyawannya). Dengan karyawan melihat atasannya bekerja keras memperkenalkan dan menjual produk maka mereka juga akan terpacu untuk berusaha. Dan selanjutnya agar pemimpin atau atasan selalu memberikan dukungan yang optimal bagikaryawannya agar mampu meningkatkan kinerja karyawan. Dukungan yang spesifik bagi karyawan melalui komunikasi yang efektif antara atasan dan bawahan akan menciptakan suasana kerja yang nyaman. Disarankan agar pemimpin lebih terlibat dalam proses atau usaha karyawan dalam memperkenalkan dan menjual produk asuransi kepada konsumen. Sementara untuk karyawan secara umum, diberikan training, pelatihan dan pengembangan diri agar karyawan lebih percaya diri dan memiliki semangat untuk menjual produk asuransi.

Dari segi motivasi, perusahaan harus terus melibatkan seluruh karyawan dalam pencapaian tujuan organisasi. Dengan adanya keterlibatan tersebut maka karyawan akan merasa senang dan merasa bahwa pekerjaan yang mereka lakukan memiliki arti bagi perusahaan sehingga hal ini akan berdampak positif bagi peningkatan kinerja mereka. Selain itu PT Asuransi Bintang juga perlu mempertimbangkan Negative Reinforcement, misalnya pemberian SP 1 untuk karyawan yang datang terlambat lebih dari 5 kali berturut-turut dalam waktu 1 bulan, menegur karyawan yang pulang sebelum jam 5 sore. Punishment, misalnya memindahkan karyawan yang tidak dapat memenuhi target, dan mendorong karyawan yang dianggap tidak capable agar mengundurkan diri. Punishment ini bertujuan untuk menghilangkan perilaku yang tidak disukai. Termasuk juga menghilangkan karyawan yang dia anggap hanya akan menjadi beban perusahaan. Positive Reinforcements, berupa rewards atau kenaikan jabatan untuk karyawan yang dapat mencapai tantangan yang dia tetapkan. Rewards ini bertujuan untuk memotivasi orang-orang yang dinilai bagus untuk terus bekerja keras untuk dapat mencapai target yang ditetapkan. Sebagai gantinya karyawan tersebut harus rela pulang diatas jam 5 sore setiap hari karena beratnya target yang ditetapkan. 


\section{Saran Untuk Penelitian Selanjutnya}

Untuk penelitian selanjutnya diharapkan mengumpulkan data dari satu kelompok sampel untuk beberapa periode waktu yang berbeda agar dapat diperoleh gambaran perubahan atau pergeseran nilai, sikap, dan perilaku karyawan pada pembentukan persepsi karyawan untuk memberikan masukan pada pihak perusahaan dalam usaha peningkatan kinerja karyawannya. Penelitian selanjutnya disarankan agar melakukan penelitian dengan menggunakan seluruh karyawan PT Asuransi Bintang, sehingga hasil penelitian yang diperoleh dapat disimpulkan secara umum atau digeneralisasi.

\section{Daftar Pustaka}

Armstrong, Gary. 2013. Philip Kotler, Geoffrey da Silva. Marketing: An Introduction An Asian Perspective. Jurong, Singapore: Pearson Education South Asia Pte Ltd.

Bourne M, Franco M, Wilkes J. 2003.Corporate Performance Management. Jurnal measuring business excellence, Volume 8 issue 4.

Burns, Alvin C. and Ronald F. Bush.2013. Marketing Research, $7^{\text {th }}$ ed. Upper Saddle River, NJ: Pearson Education.

Cascio, Wayne F. 2006.Managing Human Resources: Productivity, Quality of Work Life, Profits, $7^{\text {th }}$ ed. New York: McGrawHill.

Davis, Keith \& Newstorm, John W. 2004.Perilaku dalam Organisasi. Jakarta: Erlangga.

Donovan, J.J. 2001. Work motivation. In N. Anderson, D.S. Ones, \& H.K. Sinangil (Eds), The Handbook of Industrial, Work, and Organizational Psychology (pp. 53-76). London: Sage Publications.

Gibson, James L. \& John M. Ivancevich. 2011.Organizations Behavior,Structure, Processess. $14^{\text {th }}$ ed. New York: McGraw-Hill.

Griffin, Ricky W. and Gregory Moorhead. 2013.Organizational Behavior: Managing People and Organizations, $11^{\text {th }}$ ed. New York, NY: Hougton Mifflin Company.

Hair, Joseph F. Jr.; Black, William C.; Babin, J.Barry; Andersen, Rolph E. 2009.Multivariate Data Analysis, $7^{\text {th }}$ ed., Pearson.

Hill, Tosi., Caroll, SJ. 2007. Organizational Theory and Management: A Macro 
Approah. John Wiley and Sons Inc, New York.

Kinicki, Angelo \& Robert Kreitner.2011.Organizational Behavior: Key Concepts, Skills and Best Practices, $5^{\text {th }}$ ed. New York: McGraw-Hill.

Kouses \& Postner.2007.The Leadership Challenge, $4^{\text {th }}$ ed., Jossey-Bass, A Wiley Imprint, San Fransisco, California.

Malhotra, N.K. 2009.Marketing Research: An Applied oriented, $6^{\text {th }}$ ed. Upper Saddle River, NJ: Prentice Hall, Inc.

Mathis, Robert L.; John H. Jackson; Valentine, Sean.2014. Human Resource Management, $14^{\text {th }}$ ed. Cengage Publisher.

Michita Champathes Rodsutti; Fredric William Swierczek. 2002. Leadership and organizational effectiveness in multinational enterprises in southeast Asia. Leadership \& Organization Development Journal, Vol. 23 Iss: 5, pp.250 - 259

Muljani, Ninuk.2002.Kompensasi Sebagai Motivator Untuk Meningkatkan Kinerja Karyawan. Jurnal Manajemen \& Kewirausahaan Vol. 4, No. 2, September 2002: 108-122.

Sekaran, Uma. 2013. Research Methods for Business: A Skill-Building Approach,

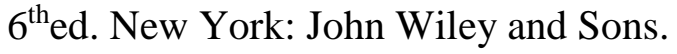

Siagian, Edison. 2003. Research Methods for Business, $4^{\text {th }}$ ed. New York, NY: John Wiley and Sons.

Simanjuntak, Payaman J. 2005.Manajemen dan Evaluasi Kinerja. Jakarta: Lembaga Penerbit Fakultas Ekonomi UI.

Wahyudin, M. \& Djumino. A. Analisis Kepemimpinan Dan Motivasi Terhadap Kinerja Pegawai Pada Kantor Kesatuan Bangsa Dan Perlindungan Masyarakat Di Kabupaten Wonogiri, 2002.

Wexley, Kenneth N. \& Yukl, Garry A., L. A. 2008.Organizational Behavior and Personnel Psychology.Boston : Richard D. Irwin, Inc. 